\title{
Association between Dictyocaulus viviparus status and milk production parameters in Dutch dairy herds
}

\author{
M. Dank, ${ }^{*}$ M. Holzhauer, $\dagger^{1}$ A. Veldhuis, $\dagger$ and K. Frankena* \\ *Quantitative Veterinary Epidemiology Group, Wageningen Institute of Animal Sciences, Wageningen University, PO Box 338 , \\ $6700 \mathrm{AH}$ Wageningen, the Netherlands \\ †GD Animal Health, PO Box 9, 7400 AA Deventer, the Netherlands
}

\section{ABSTRACT}

The objective of this study was to estimate the association between Dictyocaulus viviparus bulk tank milk (BTM) test results and milk production and milk composition parameters in adult Dutch dairy cattle herds. Bulk tank milk samples were collected in August and November 2013, and ELISA tests were performed. Two hundred BTM positive (BTM+) and 200 BTM negative (BTM-) herds were selected based on their BTM test result of November 2013, obtained from a list of farms that participated in the Dutch GD Animal Health voluntary monitoring program for controlling nematode infections. The relationship between $D$. viviparus BTM status and 3 production parameters (milk production, milk fat $\%$, and milk protein $\%$ ) in summer (June to August 2013) and autumn (September and October 2013) was investigated using generalized linear mixed models. Production data were available for 126 BTM- herds and 109 BTM+ herds. Results showed that a positive $D$. viviparus status was associated with decreased milk production (June: -1.01 , July: -1.19 , August: -1.68 , September and October: $-1.33 \mathrm{~kg} / \mathrm{cow}$ per d). Milk fat percentage was $0.14 \%$ and $0.08 \%$ lower during summer and autumn, respectively, in BTM+ herds. No significant association was demonstrated between a positive BTM test result and milk protein percentage. Because a strong correlation was present between the BTM status for D. viviparus and that for Ostertagia ostertagi, these losses cannot be attributed to one of the two parasites. However, it is clear that these parasite infections have a considerable effect on production.

Key words: Dictyocaulus viviparus, lungworm, bulktank milk, milk production

\footnotetext{
Received February 1, 2015.

Accepted June 29, 2015.

${ }^{1}$ Corresponding author: m.holzhauer@gdanimalhealth.com
}

\section{INTRODUCTION}

Bovine lungworm infections are caused by the endoparasite Dictyocaulus viviparus and are widespread among dairy cattle in moist, temperate regions (Ploeger, 2002). Disease caused by lungworm is also known as dictyocaulosis, husk or parasitic bronchitis (Taylor et al., 2007) and is mainly observed in late summer or early autumn (Matthews, 2008). In the Netherlands, 70 to $80 \%$ of dairy herds are infected with $D$. viviparus, according to the presence of lungworm larvae or presence of antibodies against lungworm (Eysker et al., 1994; Ploeger et al., 2012). In contrast, in Flanders (Belgium) herds, a prevalence of almost 20\% was reported based on bulk tank milk (BTM) samples (Bennema et al., 2009). Ploeger et al. (2014) suggested that this lower prevalence was due to a lack of sensitivity of the BTM ELISA used in the Belgian study, leading to the true prevalence being underestimated.

Before 1990, it was assumed that mainly first season grazing calves were clinically affected by $D$. viviparus infections. Later, several outbreaks among adult cattle were observed (David, 1997; Ploeger, 2002). Clinical signs being a decline of milk production, coughing, and dyspnea (Holzhauer et al., 2003). Furthermore, cattle may lose weight due to a reduced feed intake and increase in energy use by the respiratory system caused by the destructive reaction to a lungworm infection. In severe cases, lungworm infections can lead to death (Holzhauer et al., 2003).

Suspected lungworm infections can be diagnosed based on the detection of larvae in feces, antibodies in serum, or both (Ploeger et al., 2012). GD Animal Health (Deventer, the Netherlands) modified a serological ELISA to detect antibodies in BTM samples (Ploeger et al., 2012). The major advantage of BTM samples is that only one sample is required to detect $D$. viviparus infections in adult dairy cattle herds (Fiedor et al., 2009).

One of the major risk factors for increased BTM antibody levels against $D$. viviparus is access to pasture (Sekiya et al., 2013). Other suggested risk factors include 
reintroduction to pasture after permanent housing and the introduction of lungworm-naive heifers that may excrete large numbers of larvae after infection into the dairy herd, leading to re-infection of adult cattle (Holzhauer et al., 2011).

Literature regarding the effect of parasitic bronchitis on a herd's milk production is limited. Holzhauer et al. (2011) estimated that milk production of 2 Dutch dairy herds declined by 15 to $20 \%$ during a severe clinical outbreak of lungworm infection, resulting in a cost of 160 euro per cow present during the outbreak. Infections by other nematode species, such as Fasciola hepatica and Ostertagia ostertagi, are also associated with a reduced milk yield (Guitián et al., 1999; Charlier et al., 2005b; Mezo et al., 2011). Furthermore, a significant negative association between milk protein percentage - but not fat percentage - and antibody levels against $O$. ostertagi was demonstrated (Charlier et al., 2005b). For F. hepatica, a significant relationship between increased antibody levels in BTM and decreased milk fat percentage was reported (Charlier et al., 2007). It is unknown whether lungworm infections are related to milk protein percentage, milk fat percentage, or both.

The aim of this study was to determine the association between lungworm BTM test results, indicating herd-level infection with $D$. viviparus, and herd-level milk production parameters (milk yield, milk protein percentage, and milk fat percentage).

\section{MATERIALS AND METHODS}

\section{Bulk-Tank Milk ELISA}

The ELISA to detect antibodies against D. viviparus in serum is based on the initial ELISA (Ceditest Lungworm Strip Kit, Cedi Diagnostics B.V., Lelystad, the Netherlands) as described by Cornelissen et al. (1997). This ELISA was adapted for use on BTM samples (referred to as NL-BTM ELISA; Ploeger et al., 2012). It uses a partially purified low-molecular-weight antigen isolated from crude adult lungworm extracts. The ELISA results are expressed as an optical density ratio (ODR) and multiplied by 100 to interpret it as a percentage. The ODR is calculated as follows:

$$
\mathrm{ODR}=\frac{\mathrm{OD}_{\text {test sample }}-\mathrm{OD}_{\text {negative control }}}{\mathrm{OD}_{\text {positive control }}-\mathrm{OD}_{\text {negative control }}} \times 100,
$$

where OD is the optical density measured at $450 \mathrm{~nm}$.

In practice, at an ODR cutoff value of $10 \%$, the sensitivity of the NL-BTM ELISA for the detection of positive herds (within-herd prevalence $\geq 20 \%$ ) is $100 \%$ and the specificity is $38.1 \%$ (Ploeger et al., 2014). The test only detects mature infections (i.e., adult worms being present) and does not turn positive by exposure to larvae only. Test results should always be interpreted in combination with clinical symptoms.

Test results were communicated to the farmer as negative (ODR $<10 \%$ ), weak positive ( $\leq 10 \%$ ODR $<20 \%$ ), or positive (ODR $\geq 20 \%$ ) at the end of August and early November 2013. Because the cutoff value of $10 \%$ discriminates between negative and positive herds (Ploeger et al., 2014), this cutoff value was used for denoting the sample as BTM+ or BTM-.

For the ELISA used to determine specific antibody levels against $O$. ostertagi and $F$. hepatica, we refer to Charlier et al. (2005b) and Charlier et al. (2007). Both the Ostertagia (Svanovir, Uppsala, Sweden) and the Fasciola (Idexx, Westbrook, ME) ELISA were only performed at the end of the grazing period (November). The applied cutoffs for $O$. ostertagi were negative (ODR $<50 \%$ ), weak positive $(50 \% \leq$ ODR $<65 \%)$, positive $(65 \% \leq$ ODR $<90 \%)$, and high positive (ODR $\geq 90 \%$; based on a comparative study of 1 Dutch and 2 Belgian laboratories, GD Animal Health, unpublished) and for F. hepatica negative (ODR $<30 \%$ ), inconclusive $(30 \% \leq$ ODR $<90 \%)$, and positive (ODR $\geq 90 \%)$.

\section{Design and Herd Selection}

The dairy herds selected for this study were all members of the Dutch Royal Cattle Syndicate (CRV, Arnhem, the Netherlands) and participated in the voluntary GD BTM monitoring program for controlling nematode infection. In 2013, 1,741 farmers participated in this program. The BTM samples were collected twice a year (in August and early November 2013). The BTM samples in August were examined for presence of antibodies against D. viviparus, whereas BTM samples taken in November were tested for presence of antibodies against $D$. viviparus, $O$. ostertagi, and $F$. hepatica. A herd was considered BTM- if D. viviparus antibody levels did not exceed the ODR cutoff value of $10 \%$ in both August and November samples. A herd was regarded as BTM+ when at least the November sample exceeded the cutoff value of $10 \%$, which was the case for $14.3 \%$ of all participating herds. The number of herds to be included was estimated using a difference in daily milk yield of $1.25 \mathrm{~kg} /$ cow per d between BTM+ and BTM- herds ( $\mathrm{SD}=3$ ), a confidence level of $95 \%$ and a power of $80 \%$, resulting in 93 herds per group. With the expectation that over $45 \%$ (based on previous experiences) of the selected farmers would eventually provide informed consent, a total of $200 \mathrm{BTM}+$ and 200 BTM- herds were randomly selected from the database (23\% of all herds participating in the BTM program, $2.4 \%$ of all Dutch dairy herds). A stratified random 
sampling procedure was performed to select the herds, by use of Kutools for Excel v 7.50 (Detong Technology Ltd. Hainan, 2014). Figure 1 shows the geographical distribution of the selected herds.

\section{Data Collection}

A letter was sent to the selected farmers and permission was requested for access to their milk production data records. In addition, it was asked for whether cows had access to pasture in 2013 and if farmers used parasite control. Farm and milk production data [individual test-day cow milk yield, milk fat percentage, milk protein percentage, DIM, lactation number, SCC/1,000, cow health status, herd size, and geographic region (north, east, south, west)] from the period June 1, 2013, until October 31, 2013, were obtained from CRV. This time window was chosen to include the grazing season in which cows were potentially exposed to nematode larvae.

\section{Data Analysis}

To investigate nonresponse bias, $\chi^{2}$ tests were used to compare farmers that provided informed consent to use the production data (responders) with farmers that did not provide informed consent (nonresponders) regarding D. viviparus status, O. ostertagi status, $F$. hepatica status, and geographic region. Regarding the herds from which milk production data were available, descriptive statistics of BTM- herds were compared with those of BTM+ herds. All analyses were conducted using SAS 9.3 (SAS Institute Inc., 2012), and associations were regarded significant at $P \leq 0.05$.

Based on individual test-day cow production, herd averages of milk production data were computed for each monthly test day. Cows that were not representative for the herd (sick cows, cows with severe udder inflammation, and cows with one or more blind quarters) were excluded from the analysis (2.3\% of the data). Nine herds that did not have access to pasture were BTM-. These herds were excluded from the analysis because they likely received greater feed energy and therefore may bias the results. Because the BTM test results in August and November reflect a past exposure to $D$. viviparus, milk production records from preceding months were used to estimate the association between $D$. viviparus status and milk production parameters. Because we sampled BTM twice a year, and therefore had 2 test results, 2 models were made: a summer model (June-August 2013) and an autumn model (September and October 2013).

The relationship of herd average test-day milk production, milk fat percentage, and milk protein percent-

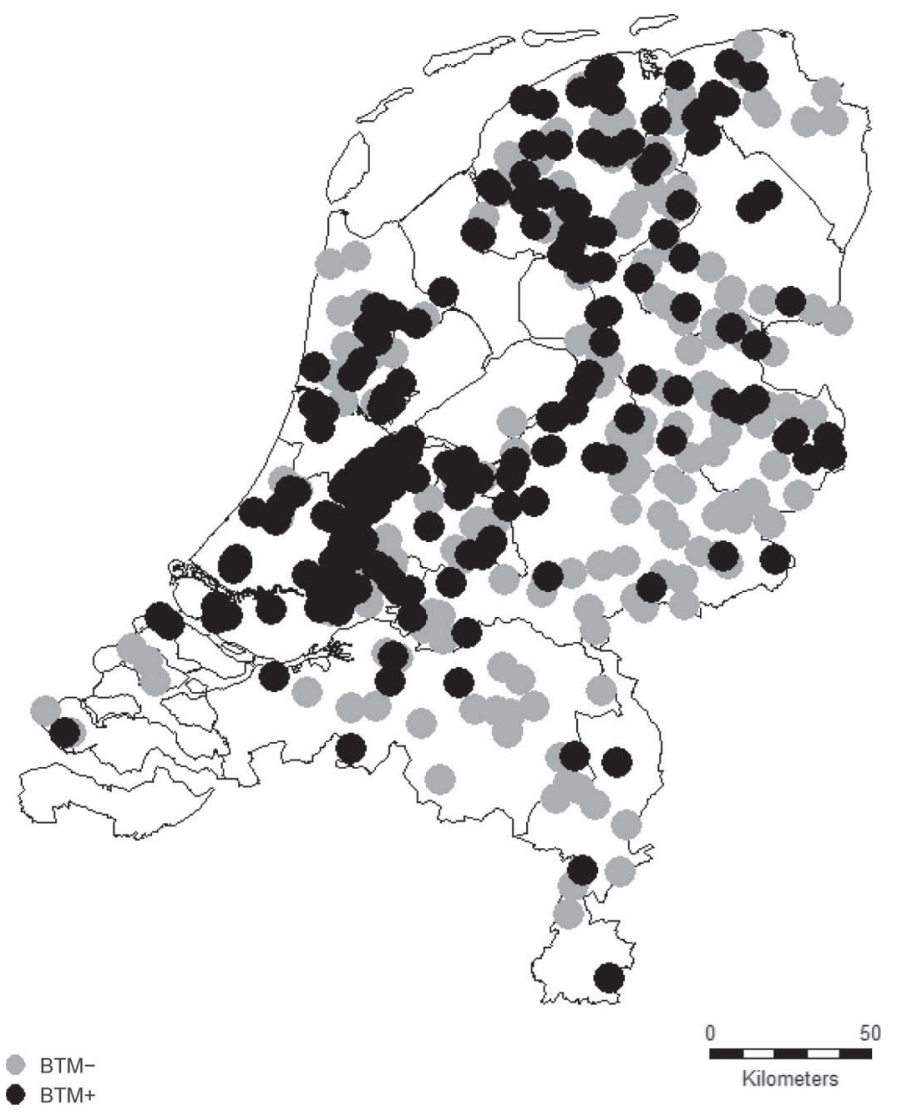

Figure 1. Geographic distribution of Dutch dairy herds $(\mathrm{n}=400)$ selected to participate in a study to assess the relation between lungworm infection and milk production parameters. BTM- = bulk tank milk negative; $\mathrm{BTM}+=$ bulk tank milk positive.

age (dependent variables) with $D$. viviparus status (independent variable) in the preceding seasons was analyzed using generalized linear mixed models (PROC GENMOD) with a normal distribution for residuals and with herd as repeated effect to account for the repeated (monthly) measurements from the same herd. The working correlation structure was compound symmetry indicating equal correlation between observations of the same herd. The summer model (measurements from June-August) was based on the BTM test result of August, the autumn model (measurements from September-October) on the BTM test result of early November. Covariates included in the models were average DIM, average lactation number, average natural $\log (\mathrm{SCC} / 1,000)$, herd size, geographic region (north, east, south, west), and month. Due to their extremely unbalanced distribution over BTM+ and BTM- groups, the variables access to pasture in 2013 (yes/no) and parasite control (yes/no) were excluded from the analyses. Because an effect of dilution could be present (e.g., an increase in milk yield corresponds to lower fat- or protein percentages when fat or protein 
yield remains constant), herd average daily milk production was also included as a covariate in the analyses to examine the relationship between $D$. viviparus status and fat and protein percentage. Additionally, milk fat percentage was included as a potential confounder in the model evaluating the effect of $D$. viviparus status on milk production. Milk fat percentage may be inversely related to milk yield as well. Final models were selected using backward elimination. The model with the smallest quasi-likelihood information criterion was selected as the best fitting model. The potential confounding effect of eliminated variables was checked by examining the change in the estimates of remaining variables. If an estimate changed more than $25 \%$, then the variable was considered a confounder and was forced back into the model. Two-way interaction terms of main effects were evaluated for significance by reviewing the $P$-value of the Wald statistic.

To investigate the relationship of concurrent parasitic infections with milk yield, O. ostertagi status, $F$. hepatica status, and their 2-way interaction terms with D. viviparus status were forced in the final model that estimated the relationship of D. viviparus status on milk production in autumn. Final model residuals were checked for normality by use of normal probability plots and for equal variances by plotting residuals against predictive values. Influential points were observed by use of Cook's D statistic and examining leverage points. An observation was classified as influential if removing the observation resulted in a change $>25 \%$ of any of the estimated coefficients.

\section{RESULTS}

Informed consent was obtained from 245 (61.25\%) of the 400 farmers to use their milk production records, 12 farmers did not grant permission and 143 did not respond. Ten farmers that gave permission to use their milk production records did not participate in the milk production recording program of CRV for the period of interest. Therefore, 235 herds remained for analysis. No significant difference was found between responders and nonresponders for $D$. viviparus status, $O$. ostertagi status, $F$. hepatica status, and geographic region $(P>$ 0.05 in all analyses).

\section{Descriptive Statistics}

Of the 235 herds used for analysis, 147 were BTM$(63 \%)$ and $88(37 \%)$ were BTM+ in August 2013. In November, 126 herds were BTM- (54\%) and 109 herds were BTM+ $(46 \%)$. Thus, 21 herds switched from BTM- in August to BTM+ in November. All herds BTM+ in August were also BTM+ in November. Almost $50 \%$ of BTM + herds in November was situated in the western part of the Netherlands $(\mathrm{n}=54)$ and 45 (41\%) BTM- herds in the eastern part. The BTMherds were significantly larger $(P<0.001)$ than BTM+ herds and had a significantly higher average milk yield and fat percentage. A description of the production parameters of BTM- and BTM+ herds, averaged over the period June 1 to October 30, 2013, is shown in Table 1. Access to pasture was given to 226 herds and 109 (48\%) of these were BTM+ in November. The 9 remaining farms did not provide access to pasture and all were BTM-. Thirty-one pastured herds were treated with anthelmintics before the lungworm test result of November. Twenty-one of these herds were tested BTM+ in November. Of the 109 BTM+ herds in November, $105(96 \%)$ tested positive for O. ostertagi and $45(41 \%)$ for F. hepatica. All herds testing positive for F. hepatica were also positive for $O$. ostertagi.

\section{Association Between Milk Production and Dictyocaulus viviparus Status}

The average of monthly test-day milk production in $\mathrm{BTM}+$ herds was lower compared with BTM- herds.

Table 1. Descriptive statistics for milk yield $(\mathrm{kg})$, protein $\%$, fat $\%$, farm size, parity, SSC, and DIM for 88 bulk tank milk positive (BTM+) dairy herds and 126 bulk tank milk negative (BTM-) dairy herds in the period from June 1 to October $30,2013^{1}$

\begin{tabular}{|c|c|c|c|c|c|c|}
\hline \multirow[b]{2}{*}{ Variable } & \multicolumn{3}{|c|}{ BTM- herds } & \multicolumn{3}{|c|}{ BTM+ herds } \\
\hline & Mean & $\mathrm{SD}$ & Range & Mean & $\mathrm{SD}$ & Range \\
\hline Herd size & 92.9 & 47.2 & 17.3 to 374.0 & 75.9 & 36.5 & 11.6 to 247.2 \\
\hline Milk yield $(\mathrm{kg} /$ cow per $\mathrm{d})$ & 26.2 & 3.0 & 18.0 to 34.9 & 24.7 & 3.1 & 16.4 to 32.7 \\
\hline Fat content in milk (\%) & 4.3 & 0.2 & 3.7 to 5.0 & 4.2 & 0.2 & 3.6 to 4.8 \\
\hline Protein content in milk $(\%)$ & 3.6 & 0.1 & 3.3 to 3.9 & 3.6 & 0.1 & 3.3 to 3.9 \\
\hline Parity & 2.8 & 0.4 & 1.9 to 4.4 & 2.8 & 0.4 & 1.8 to 3.8 \\
\hline DIM & 192 & 23 & 132. to 306 & 199 & 24 & 126 to 279 \\
\hline Natural log $(\mathrm{SCC} / 1,000)$ & 4.4 & 0.4 & 3.4 to 5.3 & 4.5 & 0.3 & 3.7 to 5.7 \\
\hline
\end{tabular}

${ }^{1}$ Herds that switched from BTM- in August to BTM+ in November were removed from the data to calculate descriptive statistics of BTM- and BTM+ dairy herds. 
In autumn (September and October 2013), the difference in milk production was $1.33 \mathrm{~kg} /$ cow per d $(P<$ $0.001)$. The working correlation was estimated as 0.87 . A significant interaction between $D$. viviparus status and month was present in the summer model; hence, stratum specific results are presented.

A BTM $+D$. viviparus status was associated with a lower milk yield of $1.01 \mathrm{~kg} /$ cow per d $(P=<0.001)$, $1.19 \mathrm{~kg} /$ cow per d $(P<0.001)$, and $1.68 \mathrm{~kg} /$ cow per $\mathrm{d}(P<0.001)$ in June, July, and August 2013, respectively (see also Table 2). The working correlation estimate was 0.83 . In an additional analysis, using the same analytic procedure, we compared the herds ( $\mathrm{n}=$ 21) that converted from BTM - in August to BTM+ in November with both BTM-/BTM- herds and BTM+/ $\mathrm{BTM}+$ herds. The estimates, $-1.04 \mathrm{~kg} /$ cow per d $(P=$ $0.20)$ and $+0.36 \mathrm{~kg} /$ cow per $\mathrm{d}(P=0.66)$, respectively, were nonsignificant.

\section{Association Between Dictyocaulus viviparus Status and Milk Quality}

A significantly negative relationship between $D$. viviparus status and milk fat percentage was observed. In summer, BTM+ herds had on average a $0.14 \%$ lower average milk fat percentage than BTM- herds $(P<$ $0.001)$. In autumn, the average reduction was $0.08 \%$ $(P=0.008)$. No significant association was observed between BTM status and milk protein percentage in either the summer $(P=0.53)$ or autumn $(P=0.27)$ model.

\section{Concurrent Infections and Milk Production}

The main effect of $F$. hepatica status $(P=0.26)$ as well as its interaction with $D$. viviparus BTM status $(P=0.78)$ in relation to milk production were not significant. Such an analysis could not be performed for $O$. ostertagi status because it was highly correlated with $D$. viviparus status; $96 \%$ of samples positive for $D$. viviparus were also positive for O. ostertagi. Subclinical mastitis did not bias the estimated effect of $D$. viviparus on milk production because the natural logarithm of (SCC/1,000) was no confounder for D. viviparus BTM status.

\section{DISCUSSION}

The D. viviparus BTM ELISA is an easy-to-apply, rapid, and noninvasive tool for detection of $D$. viviparus-infected herds. In this study we observed that a $\mathrm{BTM}+$ status has a significantly negative association with daily milk production. The estimated reductions $(-1.01 \mathrm{~kg} /$ cow per $\mathrm{d}$ in early summer up to $-1.68 \mathrm{~kg} /$ cow per d in autumn) were relatively low as compared with a study of Holzhauer et al. (2011), who described a loss of $4 \mathrm{~kg} /$ cow per $\mathrm{d}$ as a result of a D. viviparus infection in 2 dairy herds in the Netherlands. However, these herds were suffering from severe clinical lungworm outbreaks. No other studies on the association between D. viviparus status and milk production parameters, based on BTM test results, were found in literature.

Table 2. Regression coefficients, $95 \%$ confidence interval, and P-values of Dictyocaulus viviparus status (DV status) in August and November and other variables on the herd average daily milk production $(\mathrm{kg} / \mathrm{cow}$ per $\mathrm{d})$ in summer and autumn

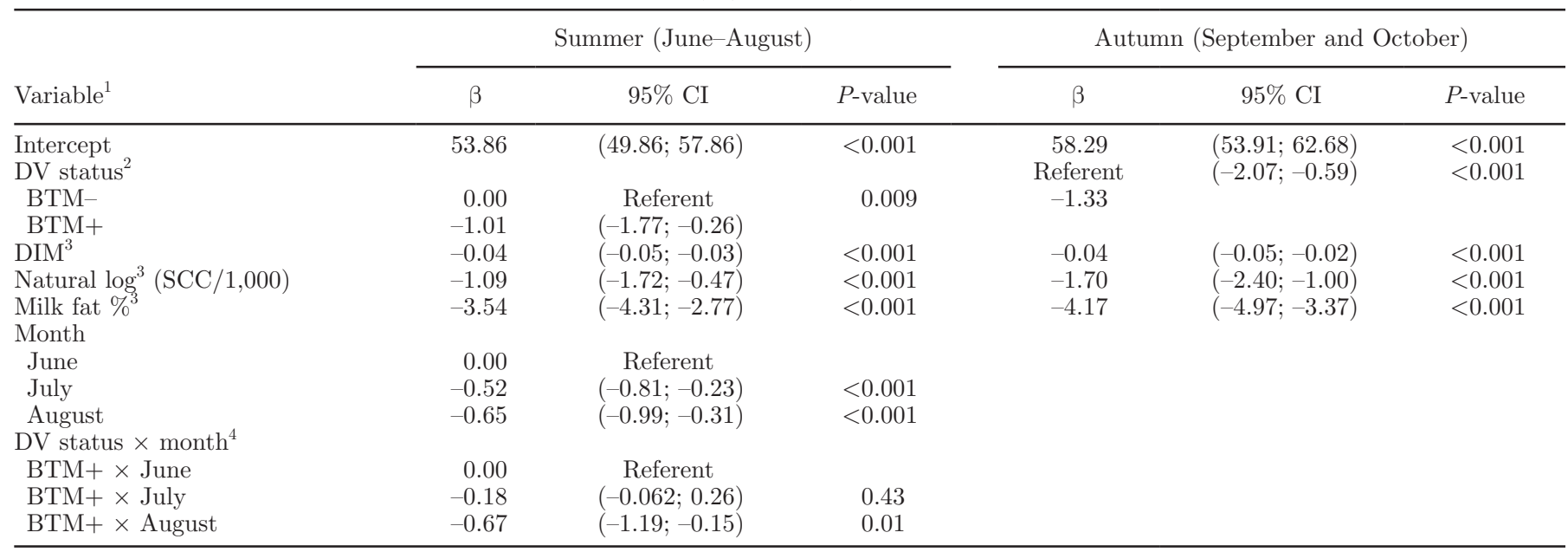

${ }^{1}$ Geographic region, herd size, and parity were not statistically significant $(P>0.05)$ and were therefore omitted from the model.

${ }^{2} \mathrm{BTM}-=$ bulk tank milk negative; BTM+ = bulk tank milk positive.

${ }^{3}$ Median and range DIM are 192 and 180, respectively; median and range milk fat \% are 4.30 and 1.43 , respectively; median and range natural $\log (\mathrm{SCC} / 1,000)$ are 4.34 and 9.21 , respectively.

${ }^{4}$ The overall $P$-value of the interaction effect was 0.04 . 
Our results are comparable with previous reports on the association between milk production and other nematode infections. Negative associations between $O$. ostertagi and milk yield were reported: $-1.25 \mathrm{~kg} / \mathrm{cow}$ per d (Guitián et al., 1999) and $-1.2 \mathrm{~kg} / \mathrm{cow}$ per d (Sanchez and Dohoo, 2002) in Canada and $-1.1 \mathrm{~kg} /$ cow per d (spring) and $-0.9 \mathrm{~kg} /$ cow per d (autumn) in Belgium (Charlier et al., 2005b). Regarding F. hepatica, negative relationships of $-0.7 \mathrm{~kg} / \mathrm{cow}$ per $\mathrm{d}$ in Belgium (Charlier et al., 2007) and $-1.5 \mathrm{~kg} /$ cow per d in Spain (Mezo et al., 2011) were reported. In addition, the Belgian study reported a reduction in the average fat percentage of $0.06 \%$ in $F$. hepatica-infected herds, which was not confirmed by the Spanish study (Charlier et al., 2007; Mezo et al., 2011). Although results of distinct studies are within the same range, it should be taken into account that comparisons are impeded by the different methods used for controlling of confounding and the length of time that milk production data was collected (Charlier et al., 2009). In addition, infection levels as well as milk production levels may differ largely between countries or regions within countries. In the Netherlands, the majority of $\mathrm{BTM}+$ herds is situated in the Western part of the country, probably due to regional differences in duration of pasturing: whole days in the Western part of the Netherlands and 6 to $8 \mathrm{~h} / \mathrm{d}$ (or permanent housing) in other parts of the country (personal communication veterinary experts GD, the Netherlands).

The negative association between $D$. viviparus status and milk production was stronger in late summer/autumn than in early summer, which coincides with the progression of the infection (Bloemhoff et al., 2015). The negative relationship between $D$. viviparus status and milk fat percentage was stronger in summer $(-0.14 \%)$ than in autumn $(-0.08 \%)$. It can be hypothesized that these reductions in milk fat percentage are due to an energy-costly immune response against $D$. viviparus as assessed under experimental conditions (Verstegen et al., 1989).

Although we evaluated several potential confounders, the association between milk production parameters and D. viviparus status should be interpreted with caution because only limited information on the herds was available. The estimates may be biased due to confounding variables that could not be included in the model [e.g., herd type (organic or conventional), breed, genetics, and $\mathrm{BW}$. In addition, it was only known whether cows had access to pasture but not for how many days a year or how long a day. If longer pasture time would lead to lower milk yield and more $D$. viviparus positive herds, then the effect of $D$. viviparus status on milk production may be overestimated.
The BTM- herds were significantly larger than $\mathrm{BTM}+$ herds. This is in agreement with a previous study of Charlier et al. (2005a) on the association between BTM antibody levels against $O$. ostertagi and herd management factors. Although BTM- herds were significantly larger than BTM+ herds, the estimated relationship between $D$. viviparus status and milk production was not affected by herd size in the final multivariable model.

Cows having (sub)clinical mastitis may affect the BTM ELISA results because an udder infection may induce a flow of specific and nonspecific antibodies from serum to the milk (Charlier et al., 2005b, 2006). Cows with clinical mastitis generally do not contribute to the BTM and because herd average SCC was included as a covariate in the regression models, we adjusted for the possible effect of subclinical mastitis. Furthermore, the natural logarithm of $(\mathrm{SCC} / 1,000)$ was no confounder for D. viviparus BTM status.

Because prevalence of helminthic infections in adult dairy cattle is high in Western Europe (Charlier, 2007), many herds are concurrently infected with multiple nematode species. In the present study, $96 \%$ of $D$. viviparus positive herds was also positive to $O$. ostertagi. Bloemhoff et al. (2015) also observed a high level of concurrent infections in Irish dairy herds where the overall prevalence of $D$. viviparus was $62.8 \%$ and of $O$. ostertagi $98 \%$. Concurrent infections may have larger pathogenic effects than the sum of the single-species infections. However, we did not observe a significant interaction between $D$. viviparus status and $F$. hepatica status. This is in agreement with a previous study that evaluated the 2-way interaction of $F$. hepatica and $O$. ostertagi (Charlier et al., 2007). Because of the strong correlation between the BTM status for $D$. viviparus and that status for $O$. ostertagi, both effects could not be analyzed simultaneously. Therefore, the estimated milk production losses cannot be attributed to one specific parasite species. However, it is clear that these parasite infections have a considerable effect on production.

A positive $D$. viviparus test result reflects past exposure to the nematode, and therefore milk production records from preceding months were used to estimate the association between $D$. viviparus status and milk production parameters. However, Fiedor et al. (2009) showed that antibodies against $D$. viviparus can be detected until 6 mo after primary infection in experimentally infected dairy cows. Therefore, it would be interesting to analyze the effect of $D$. viviparus on whole year milk production. A further refinement could be to treat ODR values as a continuous predictor instead of categorizing it. Variation in ODR between sampling dates can then be better quantified and the relationship 
between ODR and milk production parameters will be estimated more precisely.

The negative relationship between herd D. viviparus BTM status and milk production could indicate that $\mathrm{BTM}+$ herds may benefit from a more intensive parasite-control program. For that, a specific ODR threshold should be defined above which milk production losses outweigh, for example, costs of anthelmintic treatment.

\section{CONCLUSIONS}

This study showed a negative relationship between herd average milk production and herd D. viviparus status as estimated by the NL-BTM ELISA in Dutch dairy herds. In addition, we showed a negative association between $D$. viviparus status and milk fat percentage.

\section{ACKNOWLEDGMENTS}

We thank the farmers participating in this study and CRV for kindly providing the milk production records. We also thank Guillaume Counotte (GD Animal Health) for useful discussions.

\section{REFERENCES}

Bennema, S., J. Vercruysse, E. Claerebout, T. Schnieder, C. Strube, E. Ducheyne, G. Hendrickx, and J. Charlier. 2009. The use of bulktank milk ELISAs to assess the spatial distribution of Fasciola hepatica, Ostertagia ostertagi and Dictyocaulus viviparus in dairy cattle in Flanders (Belgium). Vet. Parasitol. 165:51-57.

Bloemhoff, Y., A. Forbes, B. Good, E. Morgan, G. Mulcahy, C. Strube, and R. Sayers. 2015. Prevalence and seasonality of bulk milk antibodies against Dictyocaulus viviparus and Ostertagia ostertagi in Irish pasture-based dairy herds. Vet. Parasitol. 209:108-116.

Charlier, J. 2007. The use of anti-Ostertagia ostertagi antibodies in milk to study the epidemiology and impact on production of gastrointestinal-nematode infections in dairy cows. Department of Virology, Parasitology and Immunology, Faculty of Veterinary Medicine. Ghent University, Merelbeke, Belgium.

Charlier, J., E. Claerebout, E. De Muelenaere, and J. Vercruysse. 2005a. Associations between dairy herd management factors and bulk tank milk antibody levels against Ostertagia ostertagi. Vet. Parasitol. 133:91-100.

Charlier, J., E. Claerebout, L. Duchateau, and J. Vercruysse. 2005b. A survey to determine relationships between bulk tank milk antibodies against Ostertagia ostertagi and milk production parameters. Vet. Parasitol. 129:67-75.

Charlier, J., L. Duchateau, E. Claerebout, D. Williams, and J. Vercruysse. 2007. Associations between anti-Fasciola hepatica antibody levels in bulk-tank milk samples and production parameters in dairy herds. Prev. Vet. Med. 78:57-66.

Charlier, J., L. Duchateau, F. Vangroenweghe, E. Claerebout, C. Burvenich, and J. Vercruysse. 2006. The effect of an experimentally induced acute mastitis on the test results of an Ostertagia ostertagi milk ELISA. Vet. Parasitol. 136:161-165.

Charlier, J., J. Hoglund, G. von Samson-Himmelstjerna, P. Dorny, and J. Vercruysse. 2009. Gastrointestinal nematode infections in adult dairy cattle: Impact on production, diagnosis and control. Vet. Parasitol. 164:70-79.

Cornelissen, J. B. W. J., F. H. M. Borgsteede, and F. J. van Milligen. 1997. Evaluation of an ELISA for the routine diagnosis of Dictyocaulus viviparus infections in cattle. Vet. Parasitol. 70:153-164.

David, G. P. 1997. Survey on lungworm in adult cattle. Vet. Rec. 141:343-344

Detong Technology Ltd. Hainan. 2014. Kutools for Excel: Powerful Excel Toolbox. Detong Technology Ltd. Hainan, Haikou, Hainan, China.

Eysker, M., E. W. Claessens, T. J. G. M. Lam, M. J. Moons, and A. Pijpers. 1994. The prevalence of patent lungworm infections in herd of dairy cows in the Netherlands. Vet. Parasitol. 53:263-267.

Fiedor, C., C. Strube, A. Forbes, S. Buschbaum, A.-M. Klewer, G. von Samson-Himmelstjerna, and T. Schnieder. 2009. Evaluation of a milk ELISA for the serodiagnosis of Dictyocaulus viviparus in dairy cows. Vet. Parasitol. 166:255-261.

Guitián, F. J., I. R. Dohoo, R. J. F. Markham, G. Conboy, and G. P. Keefe. 1999. Relationships between bulk-tank antibodies to Ostertagia ostertagi and herd-management practices and measures of milk production in Nova Scotia dairy herds. Prev. Vet. Med. 47:79-89

Holzhauer, M., H. W. Ploeger, and J. Verhoeff. 2003. Lungworm disease in dairy cattle: Symptoms, diagnosis, and pathogenesis on the basis of four case reports. Tijdschr. Diergeneeskd. 128:174-178.

Holzhauer, M., G. van Schaik, H. W. Saatkamp, and H. W. Ploeger. 2011. Lungworm outbreaks in adult dairy cows: Estimating economic losses and lessons to be learned. Vet. Rec. 169:494-498.

Matthews, J. 2008. Clinical Forum: Bovine lungworm. Livestock 13:23-30.

Mezo, M., M. González-Warleta, J. A. Castro-Hermida, L. Muiño, and F. M. Ubeira. 2011. Association between anti-F. hepatica antibody levels in milk and production losses in dairy cows. Vet. Parasitol. 180:237-242

Ploeger, H. W. 2002. Dictyocaulus viviparus: Re-emerging or never been away? Trends Parasitol. 18:329-332.

Ploeger, H. W., M. Holzhauer, M. Uiterwijk, and E. Van Engelen. 2014. Comparison of two serum and bulk-tank milk ELISAs for diagnosing natural (sub)clinical Dictyocaulus viviparus infection in dairy cows. Vet. Parasitol. 199:50-58.

Ploeger, H. W.. P. C. Verbeek, C. W. Dekkers, C. Strube, E. Van Engelen, M. Uiterwijk, T. J. Lam, and M. Holzhauer. 2012. The value of a bulk-tank milk ELISA and individual serological and faecal examination for diagnosing (sub)clinical Dictyocaulus viviparus infection in dairy cows. Vet. Parasitol. 184:168-179.

Sanchez, J., and I. Dohoo. 2002. A bulk tank milk survey of Ostertagia ostertagi antibodies in dairy herds in Prince Edward Island and their relationship with herd management factors and milk yield. Can. Vet. J. 43:454-459.

SAS Institute Inc. 2012. Base SAS ${ }^{\circledR} 9.3$ Procedures Guide. 2nd ed. SAS Institute Inc., Cary, NC.

Sekiya, M., A. Zintl, and M. Doherty. 2013. Bulk milk ELISA and the diagnosis of parasite infections in dairy herds: A review. Ir. Vet. J. $66: 14$.

Taylor, M. A., R. L. Coop, and R. L. Wall. 2007. Veterinary Parasitology. 3rd ed. Blackwell Publishing Ltd., Oxford, UK.

Verstegen, M. W. A., J. H. Boon, W. van der Hel, M. H. Kessels, and J. Meulenbroeks. 1989. The effects of Dictyocaulus viviparus infection on energy metabolism of calves. J. Anim. Sci. 67:241-251. 